\title{
ANALISIS HUBUNGAN ANTARA TINGKAT STRES DENGAN STATUS GIZI SISWA SD DI KOTA PALU
}

\author{
Andi Yulinda ${ }^{1}$, Dewi Suriany ${ }^{1}$, Salmah Suciaty ${ }^{1 *}$ \\ ${ }^{1}$ Program Studi Pendidikan Dokter, Fakultas Kedokteran Universitas Alkhairat, Jl. Diponegoro No. 39 \\ Palu 94221, Sulawesi Tengah, Indonesia
}

*Corresponding author: Telp: +628114536960 email: salmah.suciaty@yahoo.co.id

\begin{abstract}
ABSTRAK
Stres merupakan masalah kesehatan nomor empat didunia dan akan menjadi nomor dua pada tahun 2020. Stres tidak mengenal usia dan dapat dialami siapa saja termasuk anakanak. Penelitian ini bertujuan untuk mengetahui hubungan antara tingkat stres dengan status gizi siswa SD di Kota Palu pada masa penelitian. Penelitian ini dilakukan terhadap 269 subyek penelitian yang merupakan siswa SD di Kota Palu dari tanggal 28 November 2015 sampai 13 Februari 2016. Metode penelitian yang digunakan adalah analitik observasional dengan pendekatan cross sectional. Pengambilan sampel dilakukan dengan cara Proportionate-Stratified Random Sampling. Data diolah menggunakan perangkat lunak SPSS versi 17,0. Hasil uji mengatakan bahwa tidak ditemukan hubungan antara tingkat stres dengan status gizi siswa SD di Kota Palu ( $p>0,05$ hasil uji Spearman Correlations). Hasil uji mengatakan bahwa tidak ditemukan hubungan antara tingkat stres dengan status gizi siswa SD di Kota Palu ( $p>0,05$ hasil uji Kruskal Wallis Test) dengan perbedaan status gizi berdasarkan tingkat stres sebagai berikut tidak stres dengan status gizi normal sebesar $(61,2 \%)$, tidak stres dengan status gizi lebih $(20,7 \%)$ dan tidak stres dengan status gizi kurang $(18,1 \%)$. Stres ringan dengan status gizi normal $(62,2 \%)$ stres ringan dengan status gizi lebih $(24,3 \%)$ dan stres ringan dengan status gizi kurang $(13,5 \%)$. Kesimpulan penelitian adalah Tidak ditemukan hubungan antara tingkat stres dengan status gizi pada siswa SD di Kota Palu.
\end{abstract}

Kata Kunci : Tingkat Stres, status gizi, siswa SD

\section{ABSTRACT}

Stress is the number four health problem in the world and will be number two in 2020. Stress does not look at age and can be experienced by anyone including children. This study aims to determine the relationship between stress levels and nutritional status of elementary school students in Palu City during the study period. This research was conducted on 269 research subjects who were elementary students in Palu City from November 28, 2015 to February 13, 2016. The research method used was observational analytic with cross sectional approach. Sampling is done by Proportionate-Stratified Random Sampling. Data is processed using SPSS version 17.0 software. The test results said that there was no correlation between stress levels and nutritional status of elementary school students in Palu City ( $p>0.05$ results of the Spearman Correlations test). The test results said that there was no relationship between stress levels and nutritional status of elementary school students in Palu City ( $p>0.05$ Kruskal Wallis Test test results) with differences in nutritional status based on stress levels as follows not stressed with normal nutritional status $(61.2 \%)$, not stressed with more nutritional status $(20.7 \%)$ and not stressed with less nutritional status (18.1\%). Mild stress with normal nutritional status (62.2\%) mild stress with more nutritional status (24.3\%) and mild stress with less nutritional status (13.5\%). The conclusion of the study was that there was no association between stress levels and nutritional status in elementary school students in Palu City.

Keywords : Stress level, nutritional status, elementary school students 


\section{PENDAHULUAN}

Pada umumnya, setiap orang pernah mengalami perasaan tertekan atau mengalami ketegangan yang dalam bahasa populernya dikenal dengan istilah stres. Jika beberapa tahun yang lalu, stres lebih banyak dialami oleh usia produktif diatas 20 tahun, kini stres banyak diderita oleh anak usia remaja, bahkan dalam beberapa kasus, anakanak diperkirakan telah mengalami stres. ${ }^{1,2}$

Stres adalah reaksi atau respon nonspesifik tubuh yang menyeluruh terhadap rangsangan dari luar, baik dalam bentuk fisik maupun emosional yang menyebabkan ketidakseimbangan pada kehidupan seseorang. Stres dalam dunia anak terjadi apabila anak merasa tidak mampu untuk menahan tekanan-tekanan yang berasal dari luar dirinya (external pressure), misalnya tekanan dari teman-teman, keluarga dan sekolah; atau dari dalam dirinya sendiri (internal pressure). ${ }^{3,4,5}$

$\begin{array}{rrr}\text { Berdasarkan } & \text { berbagai penelitian } \\ \text { ditemukan stres menjadi pencetus }\end{array}$
munculnya sejumlah penyakit fisik maupun psikologik, bahkan dapat berakibat kematian pada diri seseorang yang mengalaminya. Buku-buku kedokteran mengatakan bahwa 50-70\% penyakit fisik disebabkan oleh stres. ${ }^{9} \quad$ Stres berhubungan dengan peningkatan berat badan dan penurunan berat badan. Beberapa orang memilih untuk mengkonsumsi garam, lemak dan gula untuk menghadapi ketegangan dan kemudian mengalami penambahan berat badan. Turunnya berat badan merupakan salah satu akibat yang paling non spesifik dari keadaan stres kronis. Sistem pencernaan penderita stres kemungkinan terganggu sehingga penderita tidak berselera makan karena merasa mual dan muntah- muntah. ${ }^{10}$

Anak usia sekolah yang periang bisa berubah menjadi anak yang cengeng, menjadi enggan bergaul, menolak mengerjakan pekerjaan rumah dan bahkan mungkin dengan berbagai alasan menolak berangkat sekolah. Stres pada masa anakanak yang tidak segera teratasi dapat mempengaruhi penyesuaian diri terhadap stres pada usia dewasa. ${ }^{5}$

Penelitian Gusniati terhadap siswa pada salah satu sekolah unggulan di Jakarta menemukan adanya fenomena stres yang dialami siswa disekolah sekitar 40,74\% merasa terbebani dengan keharusan memepertahankan peringkat sekolah, $62,96 \%$ siswa merasa cemas menghadapi ujian semester, $82,72 \%$ siswa merasa takut mendapat nilai ulangan yang jelek, 80,25\% merasa bingung menyelesaikan $\mathrm{PR}$ yang terlalu banyak dan 50,62\% siswa merasa letih mengikuti perpanjangan waktu belajar disekolah. ${ }^{6}$

Status gizi memiliki peranan penting terhadap pertumbuhan dan perkembangan. Dampak pada anak yang menderita gizi buruk yaitu, anak mudah menderita salah mental, sukar berkonsentrasi, rendah diri, dan prestasi belajar menjadi rendah. Dari berbagai penelitian terbukti penderita gizi buruk terjadi hambatan terhadap pertumbuhan otak dan tingkat kecerdasan. Kelainan yang terjadi pada jaringan otak akibat gizi buruk mempunyai dampak salah satunya yaitu turunnya fungsi otak yang berpengaruh terhadap kemampuan belajar. ${ }^{8}$ Turunnya berat badan merupakan salah satu akibat yang paling non spesifik dari keadaan stres kronis. Sistem pencernaan penderita stres kemungkinan terganggu sehingga penderita tidak berselera makan karena merasa mual dan muntah- muntah. ${ }^{10}$

Anak merupakan penerus bangsa. Turunnya kualitas suatu generasi dapat dicegah dengan cara menyelamatkan mereka 
dari gangguan kesehatan fisik, mental maupun intelektual. Temuan WHO (World Health Organization) yang menyebutkan bahwa "stres merupakan masalah kesehatan nomor empat didunia dan akan menjadi nomor dua pada tahun 2020”. Stres tidak mengenal usia dan dapat dialami siapa saja termasuk anak-anak. Stres dapat menyebabkan beberapa gangguan salah satunya yaitu gangguan pola makan, stres berhubungan dengan peningkatan berat badan dan penurunan berat badan. ${ }^{5,10}$

\section{METODOLOGI}

Penelitian ini merupakan penelitian observasional dengan desain cross sectional. Penelitian dilaksanakan pada 28 November 2015 sampai 13 februari 2016 di rumah dan di sekolah subyek penelitian dan di SD Alkhairaat 1 Palu, SD Inpres 8 Mamboro, SDN Inp. 2 Tanamodindi dan SDN Inp. Bumi Sagu. Populasi penelitian adalah seluruh siswa sekolah dasar di Kota Palu. Subyek penelitian adalah dua ratus enam puluh sembilan (269) siswa sekolah dasar (SD) yang terpilih dan memenuhi kriteria penelitian. Kriteria inklusi penelitian adalah siswa SD yang terpilih, siswa kelas IV dan $\mathrm{V}$, siswa berumur $10-11$ tahun, siswa perempuan dan laki-laki, siswa yang orang tuanya tinggal di Kota Palu, orang tua (responden) mengizinkan anaknya untuk ikut penelitian ini. Kriteria ekslusi penelitian adalah menderita malnutrisi berat, menderita penyakit kronis, orang tua/wali tidak dapat berkomunikasi dengan baik (bisu atau tuli).

Pengambilan data penelitian dilakukan dengan cara wawancara dan pemeriksaan fisik dengan menggunakan kuisioner dan case report pada subyek penelitian. Adapun data yang diperoleh antara lain tingkat stres, berat badan dan tinggi badan. Jumlah siswa Sekolah Dasar di Kota Palu adalah 43.422 siswa. Maka besar sampel yang dibutuhkan dalam penelitian ini adalah 269 siswa. Pengambilan sampel dilakukan dengan cara Proportionate-Stratified Random Sampling. Data diolah menggunakan perangkat lunak SPSS versi 17,0.

\section{HASIL DAN PEMBAHASAN \\ HASIL}

Tabel 1. Sebaran Siswa SD Berdasarkan

Tingkat Stres di Kota Palu

\begin{tabular}{ccc}
\hline Variabel & $\mathrm{N}$ & $\%$ \\
\hline \multicolumn{2}{c}{ Tingkat stres } \\
- $\quad$ Tidak Stres & 232 & 86,2 \\
- $\quad$ Stres Ringan & 37 & 13,8 \\
- $\quad$ Stres Sedang & 0 & 0 \\
- $\quad$ Stres Berat & 0 & 0 \\
\hline
\end{tabular}

Tabel 1 diperoleh data yang tidak stres $(86,2 \%)$ lebih banyak dari subyek dengan tingkat stres ringan, stres sedang dan berat.

Tabel 2. Sebaran Siswa SD Berdasarkan Status Gizi di Kota Palu

\begin{tabular}{|c|c|c|}
\hline Variabel & $\mathrm{N}$ & $\%$ \\
\hline \multicolumn{3}{|l|}{ Status Gizi } \\
\hline - $\quad$ Status Gizi Kurang & 47 & 17,5 \\
\hline Status Gizi Normal & 165 & 61,3 \\
\hline Status Gizi Lebih & 57 & 21,2 \\
\hline
\end{tabular}

Tabel 2 dipeoleh data status gizi normal $(61,3 \%)$ lebih banyak dibandingkan data dengan status gizi lebih $(21,2 \%)$ dan data subyek dengan status gizi kurang $(17,5 \%)$.

Tabel 3. Hubungan Tingkat Stres dengan Status Gizi

\begin{tabular}{llc}
\hline & & Skor Status Gizi (IMT) \\
\hline Skor & $\mathrm{r}$ & 0,006 \\
Tingkat & $p$ & 0,922 \\
Stres & $\mathrm{n}$ & 269 \\
\hline
\end{tabular}

Spearman Correlations $p=>0,05$

Tabel 3 menunjukkan tidak terdapat hubungan antara tingkat stres dengan status 
gizi siswa SD di Kota Palu ( $p>0,05$ hasil uji (2006) tidak terdapat hubungan status stres Spearman Correlations). Hasil penelitian ini psikososial dengan status gizi siswa SMP sejalan dengan penelitian Tirta, M. et, al $(p>0,05)$

Tabel 4. Perbedaan Status Gizi Berdasarkan Tingkat Stres

\begin{tabular}{|c|c|c|c|c|c|c|}
\hline \multirow{2}{*}{\multicolumn{2}{|c|}{ Variabel }} & \multicolumn{3}{|c|}{ Status Gizi } & \multirow[b]{2}{*}{$\begin{array}{l}\text { Total } \\
\mathrm{N} \\
(\%)\end{array}$} & \multirow[b]{2}{*}{$p$} \\
\hline & & $\begin{array}{c}\text { Gizi Kurang } \\
\mathrm{N} \\
(\%)\end{array}$ & $\begin{array}{c}\text { Gizi Normal } \\
\mathrm{N} \\
(\%)\end{array}$ & $\begin{array}{c}\text { Gizi Lebih } \\
\mathrm{N} \\
(\%)\end{array}$ & & \\
\hline \multirow[b]{2}{*}{$\begin{array}{c}\text { Tingkat } \\
\text { Stres }\end{array}$} & Tidak Stres & $\begin{array}{c}42 \\
(18,1 \%)\end{array}$ & $\begin{array}{c}142 \\
(61,2 \%)\end{array}$ & $\begin{array}{c}48 \\
(20,7 \%)\end{array}$ & $\begin{array}{c}232 \\
(100,0 \%)\end{array}$ & \multirow{3}{*}{0,746} \\
\hline & Stres Ringan & $\begin{array}{c}5 \\
(13,5 \%)\end{array}$ & $\begin{array}{c}23 \\
(62,2 \%)\end{array}$ & $\begin{array}{c}9 \\
(24,3 \%)\end{array}$ & $\begin{array}{c}37 \\
(100,0 \%)\end{array}$ & \\
\hline & $\begin{array}{c}\text { Total N } \\
(\%)\end{array}$ & $\begin{array}{c}47 \\
(17,5 \%)\end{array}$ & $\begin{array}{c}165 \\
(61,3 \%)\end{array}$ & $\begin{array}{c}57 \\
(21,2 \%)\end{array}$ & $\begin{array}{c}269 \\
(100,0 \%)\end{array}$ & \\
\hline
\end{tabular}

Kruskal Wallis $p=>0,05$

Tabel 4 menunjukkan sebagian besar subyek penelitian tidak mengalami stres dan memiliki status gizi normal. Subyek penelitian yang tidak mengalami stres dengan status gizi normal sebesar $(61,2 \%)$ lebih banyak dibandingkan subyek penelitian yang tidak mengalami stres dengan status gizi lebih yaitu sebesar $(20,7 \%)$ dan subyek penelitian yang tidak mengalami stres dengan status gizi kurang sebesar $(18,1 \%)$. Subyek penelitian yang mengalami stres ringan dengan status gizi normal sebesar $(62,2 \%)$ lebih banyak dibandingkan subyek penelitian yang mengalami stres ringan dengan status gizi lebih yaitu sebesar $(24,3 \%)$ dan subyek penelitian yang mengalami stres ringan dengan status gizi kurang yaitu sebesar (13,5\%). Tidak terdapat hubungan antara stres dengan status gizi siswa SD di Kota Palu ( $p>0,05$ hasil uji Kruskal Wallis Test).

\section{PEMBAHASAN}

Tabel 3 menunjukkan bahwa tidak ditemukan hubungan antara tingkat stres dengan status gizi. Hal ini disebabkan karena anak usia 9-12 tahun anak dapat mengatur ekspresi emosi dalam situasi sosial dan dapat berespon terhadap distress emosional yang terjadi pada orang lain. Selain itu dapat mengontrol emosi negatif seperti takut dan sedih. Anak belajar apa yang membuat dirinya sedih, marah atau takut sehingga belajar beradaptasi agar emosi tersebut dapat dikontrol. pengertian anak tentang baikburuk, tentang norma-norma aturan serta nilai-nilai yang berlaku di lingkungannya menjadi bertambah dan juga lebih fleksibel, tidak sekaku saat di usia kanak-kanak awal. Mereka mulai memahami bahwa penilaian baik-buruk atau aturan-aturan dapat diubah tergantung dari keadaan atau situasi munculnya perilaku tersebut.

Tabel 4 menunjukkan bahwa stres ringan dengan status gizi norma $(62,2 \%)$, stres ringan dengan status gizi lebih $(24,3 \%)$ dan stres ringan dengan status gizi kurang (13,5\%). Menurut Prawirohusodo (1988), timbulnya efek negatif dari stres tergantung pada kepribadian individu yang bersangkutan, status kesehatan, falsafah hidup, kekuatan keyakinan akan agama dan kepercayaan yang dianut, persepsi terhadap stres dan stres-prone (kecendrungan 
mengalami stres). ${ }^{11}$ Makan berlebih cenderung ditemukan pada penderita stres. Karena makanan terbukti dapat menimbulkan rasa nyaman. Stres diketahui juga dapat menyebabkan gangguan makan, baik berupa nafsu makan berkurang atau meningkat. Hasil penelitian ini sejalan dengan penelitian Tirta et, al (2006) yang menyatakan bahwa tidak ada hubungan yang bermakna secara statistik antara stres psikososial dengan status gizi siswa SMP Stella Duce 1 Yogyakarta $(\mathrm{p}>0,05) .{ }^{10}$

Stres pada anak juga berpengaruh terhadap tumbuh kembangnya, misalnya anak akan menarik diri, rendah diri, nafsu makan menurun atau meningkat dan sebagainya. $^{12}$ Hasil penelitian Oliver \& Wardle pada tahun 1998, menunjukkan bahwa pola makan dipengaruhi oleh stres. Perilaku ngemil dilaporkan sebesar $73 \%$ dilakukan pada saat stres. Sebaliknya, asupan buah, sayur, daging, dan ikan menurun selama mengalami stress. Faktor psikologis seperti depresi dan kecemasan dapat menyebabkan gangguan makan, baik berupa nafsu makan berkurang atau meningkat.

\section{KESIMPULAN}

Sebagian besar siswa SD di Kota Palu tidak mengalami stress, status gizi lebih lebih banyak daripada status gizi kurang dan gizi normal. Siswa SD yang stres ringan dengan status gizi lebih lebih banyak daripada siswa yang stres ringan dengan status gizi kurang $(13,5 \%)$. Tidak ditemukan hubungan antara tingkat stres dengan status gizi pada siswa SD di Kota Palu.

\section{DAFTAR PUSTAKA}

1. Sukadiyanto. 2010. Stress dan Cara Menguranginya. FIK Universitas Negeri. Yogykarta.
2. Krisnatuti, Diah. Laela, Nur. 2008. Faktor-faktor yang Mempengaruhi Tingkat Stres pada Anak Usia Sekolah Dasar yang Sibuk dan Tidak Sibuk. Program Studi Gizi Masyarakat dan Sumberdaya Keluarga, Fakultas Pertanian, Institut Pertanian Bogor. Bogor.

3. Rusmil, Kusnandi. 2010. Deteksi Dini Gangguan Psikosomatis pada Anak. Bagian Ilmu Kesehatan Anak Fakultas Kedoktereran Universitas Padjajaran. Asosiasi Kesehatan Jiwa Anak dan Remaja Indonesia (AKESWARI). Jakarta.

4. Patellongi. Ilhamjaya. 2013. Fisiologi Manusia Memahami Beberapa Aspek Homeostasis. Bagian Fisiologi Fakultas Kedokteran Universitas Hasanuddin. Leutika Books.

5. Wijayanti, Agung. 2013 Pengaruh Senam Otak Terhadap Penurunan Tingkat Stres Anak Usia Sekolah di SDN Nginden Jangkungan I Surabaya. Prodi Ilmu Keperawatan STIKES Insan Unggul Surabaya.

6. Resta, G. P. 2013. Hubungan Antara Keterlibatan Psikologis Di Sekolah Dengan Kebahagian Subjektif Peserta Didik Sekolah Menengah Pertama. Universitas Pendidikan Indonesia.

7. Supariasa, dkk. 2002. Penilaian Status Gizi. EGC. Jakarta

8. Syatyawati, Riska. 2013. Hubungan Antara Status Gizi dengan Prestasi Belajar Anak Sekolah Dasar di Desa Grenggeng Kecamatan Karanganyar Kebumen. Fakultas Kedokteran Universitas Muhamadiyah Surakarta.

9. Siswanto. 2007. Kesehatan Mental. Yogyakarta.

10. Tirta, M.P.L.K, dkk 2006. Status Stres Psikososial Dan Hubungannya Dengan 
MEDIKA ALKHAIRAAT : JURNAL PENELITIAN KEDOKTERAN DAN KESEHATAN 1(1): 6-11 e-ISSN: 2656-7822

Status Gizi Siswa SMP Stella Duce 1 Yogyakarta. Jurnal Gizi Klinik Indonesia, Volume 6, No 3. Maret 2010.

11. Best, C. et, al. 2010. The Nutriton Status of School-Aged Children.

12. Soetjiningsih. 2012. Tumbuh Kembang Anak. Penerbit Buku Kedokteran, EGC. Jakarta. 